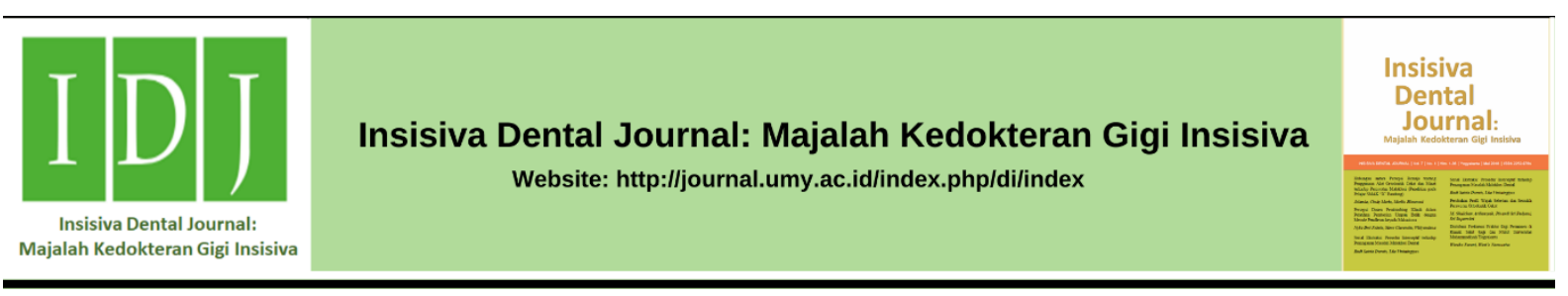

Research Article

\title{
Perbandingan Kayu Manis dan Kopi Putih terhadap Perubahan Warna Resin Akrilik Polimerisasi Dingin
}

Comparison Between Cinnamon and White Coffee Towards Color Change of Cold Polymerized Acrylic Resin

\author{
Hastoro Pintadi ${ }^{1, *}$, Tika Kartika Putri ${ }^{2}$ \\ ${ }^{1}$ Departemen Prosthodonsia, Fakultas Kedokteran dan Ilmu Kesehatan, Universitas Muhammadiyah Yogyakarta, Jalan Brawijaya, \\ Tamantirto, Kasihan, Bantul, Indonesia. \\ ${ }^{2}$ Rumah Sakit Gigi dan Mulut, Universitas Muhammadiyah Yogyakarta, Jalan HOS Cokroaminoto No. 17A, Pakuncen, Wirobrajan, \\ Yogyakarta, Indonesia.
}

Received date: November $19^{\text {th }}, 2019$; reviewed date: March $11^{\text {th }}, 2020$ revised date: June $26^{\text {th }}, 2020$; accepted date: July $1^{\text {st }}, 2020$ DOI : $10.18196 /$ di.9216

\begin{abstract}
Abstrak
Resin akrilik merupakan resin yang memiliki kejernihan luar biasa, warna dan sifat optik tetap stabil di bawah kondisi mulut normal dan secara klinis juga cukup stabil terhadap panas. Kayu manis dan kopi putih merupakan bahan minuman yang dapat menyebabkan perubahan warna pada resin akrilik. Tujuan: Mengetahui perbandingan kayu manis dan kopi putih terhadap perubahan warna resin akrilik polimerisasi dingin. Jenis: Jenis penelitian ini adalah eksperimental laboratories dengan rancangan postest control group design. Subyek yang digunakan adalah lempeng resin akrilik polimerisasi dingin dengan bentuk bulat dengan diameter $26 \mathrm{~mm}$ dan tebal $2 \mathrm{~mm}$ (ISO 1567) yang direndam dalam kayu manis dan kopi putih untuk mengevaluasi bahan yang paling banyak merubah warna resin akrilik dalam 2,5 hari. Uji perubahan warna dengan spektrofotometer, uji analisis data menggunakan independent sample t-test. Hasil: Dari uji $\Delta \mathrm{E}^{*} \mathrm{ab}=\left[\left(\Delta \mathrm{L}^{*} \mathrm{ab}\right)^{2}+\left(\Delta \mathrm{L}^{*} \mathrm{ab}\right)^{2}+(\Delta \mathrm{L} * \mathrm{ab})^{2}\right]^{1 / 2}$ didapatkan nilai rata-rata kromatisitas perubahan warna tertinggi pada perendaman dengan kayu manis yaitu 7,93368 sedangkan paling rendah pada perendaman dengan kopi putih yaitu 5,15632. Hasil nilai uji parametrik secara statistika didapatkan hasil signifikan berpengaruh. Kesimpulan: Terdapat perubahan warna resin akrilik polimerisasi dingin pada perendaman dengan kayu manis dan kopi putih.
\end{abstract}

Kata Kunci: Kayu Manis; Kopi Putih; Resin Akrilik Polimerisasi Dingin

\begin{abstract}
Acrylic resin is a resin with exceptional clarity, its color and optical properties remain stable under normal oral conditions, and it is also relatively stable against heat clinically. Cinnamon and white coffee are beverage ingredients that can cause discoloration of acrylic resin. Objective: To determine the comparison of cinnamon and white coffee to the color change of cold polymerized acrylic resin. Methods: The research type was an experimental laboratory with a posttest control group design. The subjects used were round shape cold polymerized acrylic resin plates with a diameter of $26 \mathrm{~mm}$ and a thickness of $2 \mathrm{~mm}$ (ISO 1567), which were immersed in cinnamon and white coffee to evaluate the most color-changing acrylic resin material in 2.5 days. The color change test was carried out with a spectrophotometer, while the data were analyzed using an independent sample t-test. Results: From the $\Delta E * a b=[(\Delta L * a b) 2+(\Delta L * a b) 2+(\Delta L * a b) 2] 1 / 2$ test, the highest average chromaticity value for color change was obtained in cinnamon immersion, namely 7,93368, while the lowest was immersion with white coffee, namely 5,15632. From the statistical parametric test, the results showed a significant effect. Conclusion: There was a color change of cold polymerized acrylic resin on immersion with cinnamon and white coffee.
\end{abstract}

Keywords: Cinnamon, White Coffee, Cold Polymerized Acrylic Resin

*Corresponding author, e-mail: phastoro@ymail.com 


\section{PENDAHULUAN}

fungsi diantaranya meningkatkan kemampuan dalam mengunyah, berbicara, memberikan dukungan untuk otot wajah, dan meningkatkan penampilan wajah. Pada gigi tiruan terdapat dua macam, yaitu gigi tiruan tetap dan gigi tiruan lepasan. Gigi tiruan lepasan/removable denture dibagi menjadi dua, yaitu gigi tiruan lengkap dan gigi tiruan sebagian. ${ }^{1}$ Basis gigi tiruan yang ideal harus memiliki ciri-ciri fisikal yang sesuai diantaranya yaitu biokompatibilitas, estetik yang baik, radiopak, mudah diperbaiki, dan juga harus cukup kuat agar dapat berfungsi pada beban pengunyahan yang maksimal. ${ }^{2}$

Resin akrilik yaitu resin yang memiliki kejernihan luar biasa, warna dan sifat optik tetap stabil dibawah kondisi mulut normal dan secara klinis juga cukup stabil terhadap panas. ${ }^{3}$ Resin akrilik yang digunakan dalam kedokteran gigi banyak macamnya, salah satunya resin akrilik polimerisasi dingin. Resin akrilik polimerisasi dingin disediakan dalam bentuk bubuk dan cairan. ${ }^{4}$ Resin akrilik ini memiliki keuntungan yaitu lebih ekonomis, waktu kerja lebih sedikit, dan distorsi lebih kecil. Adapun kerugiannya yaitu warnanya kurang stabil, monomer sisa lebih besar, dan kurang kuat. $^{5}$ Selama resin akrilik terpapar oleh bahan makanan dan minuman, resin akrilik cenderung menyerap berbagai kontaminan yang dapat merubah fisik dan penampilannya.

$$
\text { Tanaman kayu manis }
$$

(Cinnamomum burmanii) merupakan salah satu komoditi rempah yang menjadi barang dagangan utama sejak zaman kolonial dan sudah lama dikembangkan di Indonesia. Tanaman kayu manis dapat diolah menjadi berbagai macam produk yaitu dalam bentuk bubuk, minyak atsiri atau oleoresin. Kulit kayu manis dalam bentuk asli seperti potongan atau bubuk dapat digunakan sebagai bumbu masakan daging dan ikan, juga sebagai campuran dalam minuman (teh, kopi, dan kakao). Selain itu kulit batangnya juga mengandung tanin, dan daunnya mengandung alkaloid dan polifel. ${ }^{6}$ Dalam industri makanan, pemberi rasa dan aroma pada industri makanan, minuman, farmasi, rokok, dan kosmetika, umumnya menggunakan oleoresin dari kayu manis yang sama dengan bubuknya. Kayu manis juga dapat digunakan untuk bahan pembuat sirup dan rasa pedas sebagai penghangat tubuh karena berbau wangi dan berasa manis. ${ }^{7}$

Kopi ditemukan sekitar pada tahun 1000 SM yaitu sebagai tanaman liar dataran tinggi Ethiopia, Afrika. Kopi di Indonesia berawal dari Gubernur Belanda di Malabar mengirimkan bibit kopi arabika kepada Gubernur Belanda di Batavia, namun gagal tumbuh akibat banjir hebat melanda Batavia. Kopi putih saat ini sudah meluas penyebarannya dan banyak diminati masyarakat. Kopi memiliki banyak kandungan yang berguna bagi tubuh, salah satunya yaitu kafein yang berguna dalam penekanan pertumbuhan sel kanker, disamping rasa dan aromanya yang banyak disukai masyarakat. Cairan kopi atau zat pembawa warna tanin dari kopi hitam merupakan faktor ekstrinsik terhadap perubahan warna. Kopi putih juga banyak mengandung zat aktif (tanin) yang sama dengan kopi lainnya. Kopi dapat menghasilkan perubahan warna yang lebih banyak dibandingkan teh, soda dan air. ${ }^{8}$

Kandungan kayu manis dan kopi putih tidak hanya memiliki manfaat, beberapa bahan yang terkandung didalamnya juga dapat menghasilkan warna atau membuat perubahan warna. Sehingga kemungkinan, kayu manis dan kopi putih dapat menghasilkan warna atau terjadi perubahan warna pada resin akrilik polimerisasi dingin, apabila dikonsumsi dalam waktu tertentu.

\section{MATERIAL DAN METODE}

Jenis penelitian ini adalah eksperimental laboratories dengan rancangan posttest control group design. Penelitian dilakukan di Laboratorium 
Biokimia Fakultas Kedokteran dan Ilmu Kesehatan UMY untuk membuat larutan kopi dan kayu manis. Perendaman sampel dengan menggunakan inkubator dilakukan di Laboratorium Biokimia Fakultas Kedokteran dan Ilmu Kesehatan UMY. Pembuatan saliva buatan di Laboratorium Biokimia Fakultas Kedokteran dan Ilmu Kesehatan UMY. Laboratorium Teknik Tekstil FTI UII untuk menguji warna dengan menggunakan alat spektofotometer. Penelitian ini dilakukan pada tanggal 10 Desember 2018 sampai 3 Januari 2019.

Sampel penelitian ini menggunakan 3 sediaan yaitu kayu manis 60 gram menggunakan air mendidih sebagai perebus, kopi putih 60 gram menggunakan air mendidih $100^{\circ} \mathrm{C}$ sebagai pengencer dan saliva buatan. Subyek penelitian ini menggunakan lempeng resin akrilik polimerisasi dingin dengan bentuk bulat dengan diameter $26 \mathrm{~mm}$ dan tebal $2 \mathrm{~mm}$ (ISO 1567). Jumlah perlakuan yaitu 1 perlakuan untuk kayu manis, 1 perlakuan untuk kopi putih dan 1 perlakuan yang direndam dalam saliva sebagai kontrol.

Penelitian ini dilakukan beberapa tahapan yaitu tahapan persiapan meliputi pembuatan lempeng resin akrilik polimerisasi dingin, pembuatan resin akrilik polimerisasi dingin dibuat dengan bentuk bulat dengan diameter $26 \mathrm{~mm}$ dan tebal $2 \mathrm{~mm}$. Pada pembuatan lempeng resin akrilik dingin yaitu dengan cara polimer dan monomer resin akrilik dingin dicampur dalam stellon pot dengan perbandingan sesuai pabrik, perbandingan 3:1. Saat mencapai fase dough masukkan adonan resin akrilik ke dalam cetakan yang sebelumnya diolesi CMS. Setelah proses selesai tunggu sampai resin akrilik polimerisasi dingin mencapai setting. Selanjutnya lempeng resin akrilik polimerisasi dingin di polishing dan finishing. Setelah itu dilanjutkan dengan pembuatan larutan kayu manis, dengan cara kayu manis bubuk 60 gram direbus dengan $600 \mathrm{ml}$ air sampai mendidih dengan suhu $100^{\circ} \mathrm{C}$. Saring dan tuangkan air dari perebusan kayu manis ke dalam wadah.
Penelitian ini dilanjutkan dengan pembuatan larutan kopi putih yaitu kopi putih yang dibuat melalui proses pembekuan atau pendinginan $-40^{\circ} \mathrm{C}$. Kopi putih juga melalui proses pemanggangan setengah matang. Kopi putih dimasukkan ke dalam mesin sehingga menjadi bubuk. Kopi putih bubuk 60 gram dilarutkan kedalam $600 \mathrm{ml}$ air mendidih dengan suhu $100^{\circ} \mathrm{C}$. Selain pembuatan itu, pada penelitian ini juga membutuhkan saliva buatan dengan $\mathrm{pH}$ 6,7 menurut Van Houver yang dibuat di Laboratorium Biokimia Fakultas Kedokteran dan Ilmu Kesehatan UMY. elaksanaan penelitian yaitu semua sampel sebanyak 30 direndam dalam saliva buatan dan diinkubasi dengan suhu $37^{\circ} \mathrm{C}$ selama 24 jam dengan cara meletakkan lempeng akrilik sejajar dengan dasar wadah sehingga tidak tumpang tindih dan ditutup dengan menggunakan almunium foil. Setelah direndam saliva selama 24 jam, 30 sampel dicuci dan dikeringkan. Selanjutnya dibagi beberapa kelompok yaitu 1 kelompok sebagai kontrol direndam dalam saliva buatan, sedangkan 20 sampel lainnya dibagi menjadi 2 kelompok perendaman yaitu larutan kayu manis dan larutan kopi putih. Setiap kelompok diberi 10 sampel. Cara perendaman sampel yaitu diinkubasi didalam inkubator dengan suhu $37^{\circ} \mathrm{C}$. Sampel direndam dalam larutan kayu manis dan larutan kopi putih sampai semua bagian lempeng akrilik tercelup, setelah itu tempat perendaman ditutup rapat dan diinkubasi didalam inkubator dengan suhu $37^{\circ} \mathrm{C}$. Perendaman dilakukan selama 2,5 hari. Sampel dikeluarkan kemudian dicuci dan dikeringkan dan dilihat menggunakan Spektofotometer untuk mengetahui perubahan warna yang terjadi. Hasil dari pengukuran nilai warna pada perendaman sampel dengan saliva ditetapkan sebagai kelompok kontrol. Perbedaan antara 2 warna dapat ditentukan dari rumus warna: $\Delta \mathrm{E}^{*} \mathrm{ab}=\left[\left(\Delta \mathrm{L}^{*} \mathrm{ab}\right)^{2}+\left(\Delta \mathrm{L}^{*} \mathrm{ab}\right)^{2}+\left(\Delta \mathrm{L}^{*} \mathrm{ab}\right)^{2}\right]$ $\Delta \mathrm{E}^{*} \mathrm{ab}=\left[\left(\mathrm{L}^{*}{ }_{0}-\mathrm{L}^{*}\right)^{2}+\left(\mathrm{a}^{*}{ }_{0}-\mathrm{a}^{*}\right)^{2}+\left(\mathrm{b}^{*}{ }_{0}\right.\right.$ $\left.\left.-b^{*}\right)^{2}\right]$ 
HASIL

Hasil penelitian perbandingan perendaman resin akrilik polimerisasi dingin dalam kopi putih dan kayu manis selama 2,5 hari pada 3 kelompok yang terdiri dari tiap kelompok 10 sampel diukur menggunakan alat Spektrofotometer sehingga didapatkan nilai kromartisitas sebagai berikut:

Tabel 1. Nilai kromatis resin akrilik

\begin{tabular}{ccc}
\hline \multirow{2}{*}{ Sampel } & \multicolumn{2}{c}{ Larutan } \\
\cline { 2 - 3 } & Kopi Putih & Kayu Manis \\
\hline 1 & 4,2721 & 8,4606 \\
2 & 3,9430 & 3,8599 \\
3 & 4,2658 & 10,9663 \\
4 & 4,8375 & 7,2359 \\
5 & 3,2327 & 7,4985 \\
6 & 3,4440 & 8,9759 \\
7 & 9,3139 & 7,8870 \\
8 & 8,1224 & 11,7684 \\
9 & 7,9480 & 8,3828 \\
10 & 2,1838 & 4,3015 \\
& & \\
\hline Total & 51,5632 & 79,3368 \\
Rata-rata & 5,15632 & 7,93368 \\
\hline
\end{tabular}

Berdasarkan tabel 1 terlihat bahwa nilai kromatisasi $\Delta \mathrm{E}^{*} \mathrm{ab}\left(\mathrm{L}^{*} \mathrm{a} * \mathrm{~b}\right)$ resin akrilik polimerisasi dingin yang direndam dalam kopi putih dan kayu manis mengalami perbedaan. Nilai rata-rata kromatisasi perubahan warna tertinggi pada perendaman dengan kayu manis yaitu 7,93368, sedangkan yang terendah yaitu pada perendaman dengan kopi putih 5,15632 .

Perbandingan perendaman resin akrilik polimerisasi dingin dalam kopi putih dan kayu manis diuji normalitas terlebih dahulu sebelum diuji analisis data sebagai berikut:

Tabel 2. Ringkasan hasil uji satistik nilai kromatisasi resin akrilik polimerisasi dingin

\begin{tabular}{ccc}
\hline $\mathrm{T}$ & $\mathrm{df}$ & Sig. (2-tailed) \\
\hline-2.350 & 18 & 0.021 \\
\hline
\end{tabular}

Tabel 2 di atas menunjukkan bahwa t hitung adalah -2.350 dengan probabilitas 0.021 . Oleh karena probabilitas $<0.05$ maka terdapat perbedaan rerata perubahan warna bermakna antara kelompok yang direndam dengan kopi putih dan kayu manis.

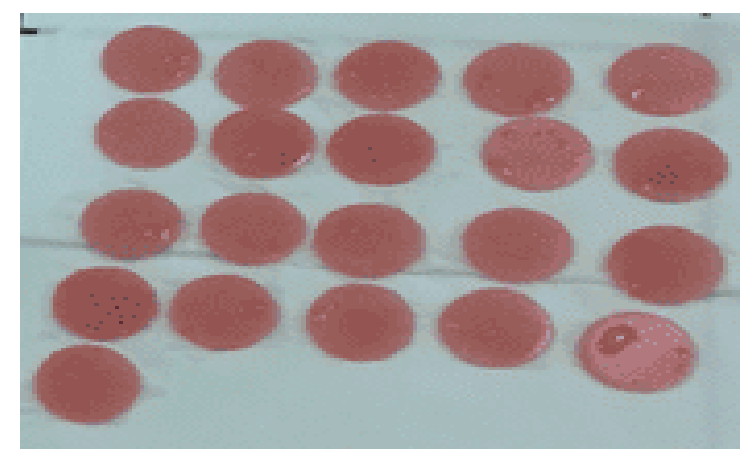

Gambar 1. Plat akrilik sebelum perendaman kayu manis dan kopi putih

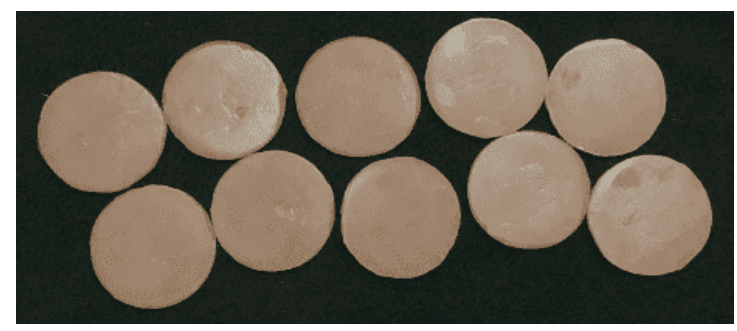

Gambar 2. Plat akrilik sesudah perendaman kayu manis

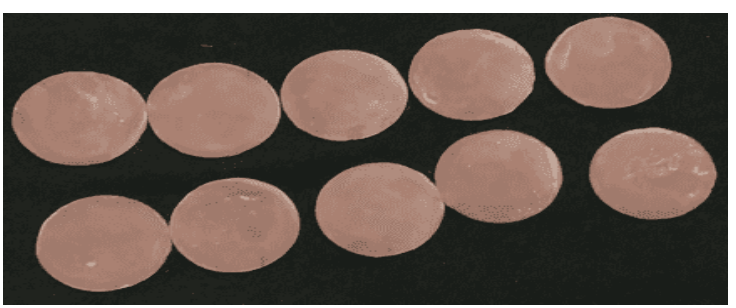

Gambar 3. Plat akrilik sesudah Perendaman Kopi Putih

\section{PEMBAHASAN}

Penelitian ini dilakukan pengujian perendaman resin akrilik polimerisasi dingin dalam kopi putih dan kayu manis untuk mengetahui perbandingan perubahan warna yang terjadi pada sampel. Perendaman dilakukan dengan 3 kelompok selama 2,5 hari. Hasil pengukuran nilai rata-rata kromatisasi dengan menggunakan alat Spektrofotometer dan dievaluasi dengan system Commission International de L'Eclairage (CIE L*a*b* yang berdasarkan pada 3 parameter warna yaitu 
$\mathrm{L}^{*}, \mathrm{a}^{*}, \mathrm{~b}^{*} . \mathrm{L}^{*}$ adalah Lightness, $\mathrm{a}^{*}$ adalah representasi warna merah-hijau, $b^{*}$ adalah representasi warna kuning-biru. Untuk memperoleh nilai perubahan warna atau nilai kromatisasi maka digunakan rumus sebagai berikut $\Delta \mathrm{E}^{*} \mathrm{ab}=\left[\left(\Delta \mathrm{L}^{*} \mathrm{ab}\right) 2+\right.$ $\left.\left(\Delta \mathrm{L}^{*} \mathrm{ab}\right) 2+\left(\Delta \mathrm{L}^{*} \mathrm{ab}\right) 2 \mathrm{C}\right] 1 / 2$ didapatkan hasil pada kelompok kopi putih dan kayu manis mengalami perubahan warna.

Hasil perhitungan uji normalitas menunjukkan bahwa nilai kromatisasi perendaman dengan kopi putih dan kayu manis menunjukkan bahwa distribusi pada setiap kelompok perlakuan adalah normal, maka selanjutnya dilakukan uji analisis data parametrik. Hasil uji homogenitas didapatkan nilai probabilitas yaitu 0,753 , karena nilai probabilitas $>0,05$ maka ketiga varian adalah sama. Hasil uji hipotesis nilai kromatisasi resin akrilik polimerisasi dingin menunjukkan bahwa nilai probabilitas 0.021 . Oleh karena probabilitas $<0.05$ maka terdapat perbedaan rerata perubahan warna bermakna antara kelompok yang direndam dengan kopi putih dan kayu manis. Hasil penelitian ini tidak sesuai dengan hipotesis penelitian yaitu kopi putih lebih banyak merubah warna dibandingkan dengan kayu manis. Berdasarkan nilai rata-rata data sampel menunjukkan bahwa kayu manis lebih tinggi dibandingkan dengan kayu putih. perubahan warna ini dibuktikan dengan hasil penelitian yang telah dianalisis menggunakan uji parametrik yang juga diperkuat oleh beberapa pernyataan peneliti dan para ahli sebelumnya. Perendaman resin akrilik di dalam suatu larutan dapat menyebabkan terjadi perubahan warna. Hal ini disebabkan adanya proses penyerapan air pada resin akrilik polimerisasi dingin yang terjadi secara difusi, dimana berpindahnya suatu substansi melalui rongga, atau melalui substansi kedua. Molekul air menembus massa poli metil metrakilat dan menempati posisi diantara rantai polimer, rantai polimer yang terganggu dipaksa memisah. Sehingga, menimbulkan efek yaitu massa terpolimerisasi mengalami sedikit ekspansi dan molekul air mempengaruhi kekuatan rantai polimer. Melemahnya ikatan makromolekul tersebut kemungkinan menyebabkan terlepasnya pigmen dari lempeng resin akrilik polimerisasi dingin sehingga memudarkan warna lempeng resin akrilik heat cured. ${ }^{9}$ kedua bahan ini yaitu kopi putih dan kayu manis mengandung tanin yang dapat menghasilkan perubahan warna pada resin akrilik polimerisasi dingin. Kandungan tanin memiliki peran penting dalam perubahan warna tersebut.

Biji kopi (green coffee) adalah biji kopi yang berwarna hijau sudah terlepas dari daging buah, kulit tanduk, dan kulit arinya serta telah mengalami pengeringan sehingga mengandung kadar air di bawah $12 \% .{ }^{10}$ Kopi mempunyai kandungan selain asam yaitu mengandung senyawa asam galat golongan tanin yang mempunyai gugus kromofor. Gugus kromofor dapat menyebabkan suatu zat atau molekul terlihat berwarna karena gugus ini berupa cincin aromatik (benzena). ${ }^{11}$ Sedangkan pada kayu manis mengandung tannin yang merupakan pewarna alami yang mempunyai sifat larut dalam air, tidak dapat mengkristal dan bersenyawa dengan protein dari larutannya. ${ }^{12}$ Zat warna tanin juga akan diserap oleh resin akrilik melalui porositas dan akan menyebabkan perubahan warna. Hal ini sesuai dengan pernyataan Togatorop yang menyatakan bahwa pada senyawa tanin mengandung polifenol yang bersifat asam sehingga dapat menganggu reaksi hidrolisis antara fenol dan ester polimetil metakrilat pada plat resin akrilik sehingga terjadi banyak rongga atau porus pada permukaan plat resin akrilik. Hal ini menyebabkan adanya difusi cairan kopi yang masuk kedalam plat resin akrilik akibatnya terjadi perubahan volume larutan kopi yang dapat mengakibatkan perubahan warna pada plat resin akrilik karena terjadi peningkatan absorbsi zat tannin. ${ }^{13}$

Hasil penelitian ini tidak sesuai dengan pernyataan beberapa peneliti yang menemukan bahwa kopi menghasilkan 
perubahan warna yang lebih banyak dibandingkan dengan teh, soda dan air. ${ }^{8}$ Kopi putih yang digunakan pada penelitian ini merupakan kopi putih kemasan, sehingga tidak hanya terdapat kopi putih murni tetapi juga campuran bahan-bahan lain salah satunya yaitu gula. Selain itu, pada kemasan ini hanya mengandung kopi putih murni sebanyak $19 \%$ per kemasan.

Penelitian yang dilakukan sebelumnya menyatakan bahwa penambahan gula pasir menunjukkan penurunan kadar total fenol dan kadar tanin yang paling besar, sehingga kemungkinan juga terjadi penurunan kadar tanin pada kopi putih yang menyebabkan kopi putih tidak dapat menghasilkan perubahan warna lebih banyak atau lebih maksimal. ${ }^{14}$ Kopi putih kemasan yang digunakan pada penenilitian ini hanya mengandung $38 \%$ kopi putih murni dari berat keseluruhan yaitu 60 gram, sehingga yang terkandung didalam kemasan ini kurang lebih hanya 11,4 gram kopi putih murni sehingga kemungkinan kadar tanin lebih sedikit dibandingkan dengan kayu manis, karena kayu manis yang digunakan adalah kayu manis murni. penelitian sebelumnya dalam 10 gram kopi robusta mengandung tanin sebanyak $3,1 \%$, sehingga kemungkinan kadar tanin yang terdapat pada penelitian ini pun tidak jauh berbeda dengan penelitian sebelumnya. ${ }^{15}$ Selain itu takaran atau banyaknya bubuk kayu manis yang dipakai jumlahnya cukup banyak, karena dari hasil penelitian yang dilakukan sebelumnya yaitu pada takaran 4 gram kayu manis yang dipakai sudah dapat menghasilkan warna coklat. ${ }^{16}$ penelitian ini menggunakan kayu manis sebanyak 60 gram, Kualitas kayu manis dipengaruhi oleh sejumlah faktor salah satunya yaitu metode pemotongan dan produksi, tetapi tidak terdapat atau belum ditemukan perbedaan yang terlalu berpengaruh pada kandungan dalam kayu manis kecuali sinnamaldehide. ${ }^{17}$

Hasil nilai uji parametrik secara statistk didapatkan nilai signifikansi sebesar 0,021 yang berarti bahwa terdapat perbedaan rerata perubahan warna bermakna antara kelompok yang direndam dengan kopi putih dan kayu manis.

\section{KESIMPULAN}

Perendaman resin akrilik polimerisasi dingin dengan kayu manis memiliki nilai rata-rata kromatisitas perubahan warna tertinggi sebesar 7,93368 sedangkan perendaman dengan kopi putih menghasilkan nilai kromatisasi terendah sebesar 5,15632. Perubahan warna lempeng resin akrilik polimerisasi dingin pada kayu manis lebih banyak dibandingkan pada kopi putih.

\section{DAFTAR PUSTAKA}

1. Wahjuni $\mathrm{S}$, \& Mandanie SA. Fabrication of Combined Prosthesis with Castable Extracoronal Attachments (Laboratory Procedure). Journal of Vocational Health Studies. 2017;1(2):75-81.

2. Kangsudarmanto $\mathrm{Y}$, Rachmadi P, I Wayan AKF. Perbandingan Perubahan Warna Heat Cured Acrylic Basis Gigi Tiruan yang Direndam dalam Klorheksidin Dan Effervescent (Alkaline Peroxide). Dentino JKG. 2014;2(2):205-209.

3. Naini, A. Pengaruh Berbagai Minuman Terhadap Stabilitas Warna Resin Akrilik. Stomatognatik (J.K.G. UNEJ). 2011;8(2):74-77.

4. Gladwin M, \& Bagby M. Clinical Aspects of Dental Materials (3 ed.). Lippincott Williams \& Wilkins. 2004:56-59.

5. Goenharto, S. Bahaya bagi teknisi dental laboratorium pada pembuatan peranti ortodonti lepas. Jurnal PDGI. 2016;65(1):6-11.

6. Kementrian Kesehatan RI. 100 Top Tanaman Obat Indonesia. Badan Penelitian dan Pengembangan Tanaman Obat dan Tradisional. 2011. 
7. Ferry Y. Prospek Pengembangan Kayu Manis (Cinnamomum Burmanii L) di Indonesia. J SIRINOV. 2013;1:11-20.

8. Supiyana, Sidiqa AN, Sukma N. Perbedaan Diskolorisasi resin komposit hybrid yang direndam dengan larutan kopi hitam dan kopi putih. Jurnal Material Kedokteran Gigi. 2013;2(2):161-168.

9. Anusavice, \& Rawls RH. Science of Dental Materials (Eleventh ed). Saunders. 2003:734-746.

10. Nopitasari I. Proses Pengolahan Kopi Bubuk (Campuran Arabika dan Robusta) Serta Perubahan Mutunya Selama Penyimpanan. IPB Bogor. 2010:1-92.

11. Ifwandi, Sari D V, Lismawati. Pengaruh Perendaman Elemen Gigi Tiruan Resin Akrilik dalam Larutan Daun Sirih (Piper Betle Linn) terhadap Perubahan Warna. Cakradonya Dent J. 2013;5(2):542-618.

12. Kusstianti N, Karyaningrum EA, Wilujeng YB. Pengaruh Penggunaan Bubuk Kayu Manis dan Cengkeh sebagai Warna Rambut Beruban. Prosiding Seminar Nasional Vokasi Indonesia. 2018:1.
13. Togatorop SR, Rumampuk FJ, Wowor SNV. Pengaruh Perendaman Plat Resin Akrilik dalam Larutan Kopi dengan Berbagai Kekentalan Terhadap Perubahan Volume Larutan Kopi. Jurnal E-Gigi. 2017;5(1):19-23.

14. Andriani M, Amanto SB, Gandes. Pengaruh Penambahan Gula dan Suhu Penyajian terhadap Nilai Gisi Minuman Teh Hijau. Jurnal Teknologi Hasil Pertanian. 2012;5(1):40-47.

15. Chismirina S, Andayani R, Ginting R. Pengaruh Kopi Arabika (Coffea Arabica) dan Kopi Robusta (Coffea Canephora) terhadap Viskositas Saliva Secara In Vitro. Cakradonya Dent J. 2014;6(2):678-744.

16. Utarid GR. Pengaruh Proporsi Tepung Pati Singkong dan Bubuk Kayu Manis (Cinnamomum Burmannii) terhadap Sifat dan Masa Simpan Fisik Masker Wajah Tradisional. e-Jurnal. 2018;7(2):93-99.

17. Praputri E, \& Sundari E. Pengambilan Minyak Atsiri Berdasarkan Ketinggian Pengulitan dan Dari Bagian Tanaman Kayumanis yang Terbuang. Jurnal Teknos-2k. 2008;8(1):55-58. 